Article

\title{
Cytostatic Action of Novel Histone Deacetylase Inhibitors in Androgen Receptor-Null Prostate Cancer Cells
}

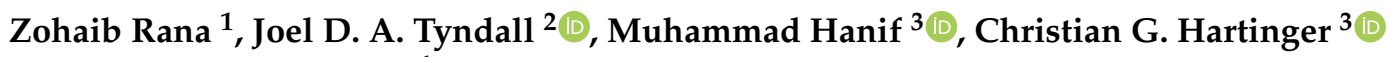 \\ and Rhonda J. Rosengren ${ }^{1, *}$ \\ 1 Department of Pharmacology and Toxicology, University of Otago, Dunedin 9016, New Zealand; \\ ranzo073@student.otago.ac.nz \\ 2 School of Pharmacy, University of Otago, Dunedin 9016, New Zealand; joel.tyndall@otago.ac.nz \\ 3 School of Chemical Sciences, University of Auckland, Auckland 1142, New Zealand; \\ m.hanif@auckland.ac.nz (M.H.); c.hartinger@auckland.ac.nz (C.G.H.) \\ * Correspondence: rhonda.rosengren@otago.ac.nz; Tel.: +64-3-479-9141
}

Citation: Rana, Z.; Tyndall, J.DA; Hanif, M.; Hartinger, C.G; Rosengren, R.J Cytostatic Action of Novel Histone Deacetylase Inhibitors in Androgen Receptor-Null Prostate Cancer Cells. Pharmaceuticals 2021, 14, 103. https://doi.org/10.3390/ph14 020103

Academic Editors: Raquel Lima and Marcelo Correia

Received: 22 December 2020

Accepted: 25 January 2021

Published: 29 January 2021

Publisher's Note: MDPI stays neutral with regard to jurisdictional claims in published maps and institutional affiliations.

Copyright: (c) 2021 by the authors. Licensee MDPI, Basel, Switzerland. This article is an open access article distributed under the terms and conditions of the Creative Commons Attribution (CC BY) license (https:// creativecommons.org/licenses/by/ $4.0 /)$.

\begin{abstract}
Androgen receptor (AR)-null prostate tumors have been observed in $11-24 \%$ of patients. Histone deacetylases (HDACs) are overexpressed in prostate tumors. Therefore, HDAC inhibitors (Jazz90 and Jazz167) were examined in AR-null prostate cancer cell lines (PC3 and DU145). Both Jazz90 and Jazz167 inhibited the growth of PC3 and DU145 cells. Jazz90 and Jazz167 were more active in PC3 cells and DU145 cells in comparison to normal prostate cells (PNT1A) and showed a 2.45- and 1.30-fold selectivity and higher cytotoxicity toward DU145 cells, respectively. Jazz90 and Jazz167 reduced HDAC activity by $\sim 60 \%$ at $50 \mathrm{nM}$ in PC3 lysates. At $4 \mu \mathrm{M}$, Jazz90 and Jazz167 increased acetylation in PC3 cells by 6- to 8-fold. Flow cytometry studies on the cell phase distribution demonstrated that Jazz 90 causes a $G_{0} / G_{1}$ arrest in AR-null cells, whereas Jazz167 leads to a $G_{0} / G_{1}$ arrest in DU145 cells. However, apoptosis only occurred at a maximum of $7 \%$ of the total cell population following compound treatments in PC3 and DU145 cells. There was a reduction in cyclin D1 and no significant changes in bcl-2 in DU145 and PC3 cells. Overall, the results showed that Jazz90 and Jazz167 function as cytostatic HDAC inhibitors in AR-null prostate cancer cells.
\end{abstract}

Keywords: HDAC inhibitors; cancer chemotherapy; prostate cancer; pyridinecarbothioamide; metallodrugs; anticancer agents

\section{Introduction}

Nearly 1.3 million new cases of prostate cancer were diagnosed in 2018, making it the second-most commonly diagnosed cancer and cause of fatalities in men [1]. Since 2005 , a $66 \%$ increase in the incidence of prostate cancer has been observed due to an aging population [1,2]. Initially, prostate cancer is dependent on serum androgen levels, and therefore, androgen deprivation therapy is particularly effective [3]. However, after a median time of 18-24 months, the majority of patients develop castration-resistant prostate cancer (CRPC), where tumors grow in the absence of androgens, even though androgen receptors (ARs) are present $[4,5]$. Recently, studies have also reported that CRPC differentiates into a highly aggressive transdifferentiated AR-null/deficient/low heterogenous phenotype with or without a neuroendocrine phenotype [6-8]. Approximately 11-24\% of patients develop this phenotype [6,9] and become resistant to enzalutamide, a Food and Drug Administration (FDA)-approved AR antagonist [6]. From a mechanistic viewpoint, abiraterone acetate and enzalutamide, which target the AR signaling pathways, are the only FDA-approved drugs for prostate cancers, but these drugs are not effective against AR-null prostate cancers [10]. Only one phase II trial using carboplatin and etoposide in AR-null tumors has been conducted. An objective response was only seen in 4 out of 56 patients according to the response evaluation criteria in solid tumors, and an overall 
survival of 9.6 months was reported [11]. Therefore, no FDA-approved treatment options are available for AR-null prostate cancer phenotypes.

Epigenetic modifications are a common feature of cancers, where gene expression is deregulated [12]. In these processes, acetylation and deacetylation of histones are critical in regulating gene expression [12]. Histone has an octamer structure flanked with tails. Following deacetylation by histone deacetylases (HDACs), the histone tails gain a positive charge and adhere to the negatively charged phosphate backbone of the DNA. In this state, gene transcription remains silent [13]. Histone acetyltransferases can add acetyl groups, resulting in the removal of positive charges. Consequently, the interaction between the phosphate backbone and histone tails are broken, leading to transcriptional activity [13].

HDACs are upregulated in a plethora of solid and hematological malignancies [13], which is linked to a poor clinical outcome [14]. Weichert and colleagues demonstrated that HDAC1, HDAC2, and HDAC3 are overexpressed in prostate cancers, whereas increased expression of HDAC1 and HDAC2 correlates with higher Gleason scores. The proliferative marker Ki67 showed a positive association with HDAC1, 2, and 3 [15]. Interestingly, studies report that HDAC1 has a repressive effect on the levels of androgen in prostate cancer cells, which in turn can be reversed by SENP1 expression [16]. Chiao and colleagues (2009) also showed that the AR-null cell lines PC3 and DU145 possess three to four times higher HDAC activity in comparison to the AR+ (LnCaP) cell line [17]. Therefore, HDAC inhibitors are likely to be more useful in an AR-null environment in comparison to an AR+ environment. The poor efficacy of HDAC inhibitors in clinical trials for CRPC are likely to be attributed to the lack of assessment of AR expression. HDAC inhibitors (romidepsin, Vorinostat or suberoylanilide hydroxamic acid (SAHA), panobinostat, and pracinostat) are well tolerated by patients and have been FDA approved for hematological malignancies, and an HDAC inhibitor (chidamide) has cleared phase III clinical trials in combination with exemestane for locally advanced or metastatically recurrent hormone receptor-positive breast cancer [18-22].

We have previously synthesized the novel HDAC inhibitors N1-hydroxy- $N^{8}$-(4(pyridine-2-carbothioamido)phenyl)octanediamide (Jazz90) and [chlorido( $\eta^{5}$-pentamethylcyclopentadienyl) (N1-hydroxy- $N^{8}$-(4-(pyridine-2-carbothioamido- $\kappa^{2} N, S$ )phenyl)octanediamide)rhodium(III)] chloride (Jazz167) (Figure 1), which are structural analogues of SAHA [23]. Substitution of the phenyl group of SAHA for a pyridinecarbothioamide moiety yielded Jazz90. It was then coordinated to $\mathrm{Rh}$ (pentamethylcyclopentadienyl)Cl to obtain Jazz167. Jazz90 and Jazz167 consist of an additional aromatic ring in comparison to SAHA, which could potentially improve the lipophilicity of these compounds, ultimately leading to an improved volume of distribution [24]. Alongside HDAC1, 6, and 8 inhibition, Jazz90 and Jazz167 possessed cytotoxic activity against colorectal, lung, and cervical cancer cells. Minimal hemolytic activity $(10 \%)$ was recorded at high concentrations of $200 \mu \mathrm{M}$. In comparison, cisplatin, an FDA-approved metal-based drug for bladder cancer, exhibited 100\% hemolytic activity at $200 \mu \mathrm{M}$ [23]. Similarly, organometallic pyridinecarbothioamide compounds featuring osmium and ruthenium centers have also exhibited cytotoxicity against $\mathrm{CH} 1$ (ovarian), SW480 (colorectal), and A549 (lung) cancer cells [25]. 
<smiles>O=C(CCCCCCC(=O)Nc1ccccc1)NO</smiles><smiles>O=C(CCCCCCC(=O)Nc1ccc(NC(=S)c2ccccn2)cc1)NO</smiles>

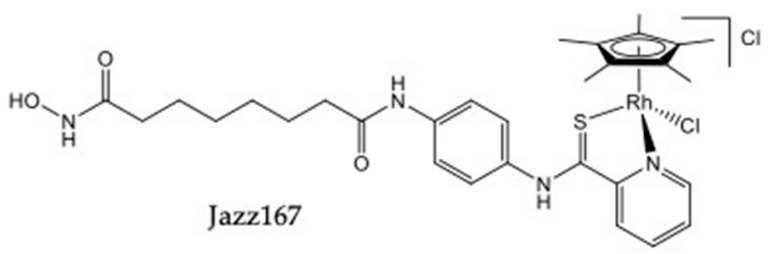

Figure 1. Structures of SAHA, Jazz90, and Jazz167.

Due to the role of HDAC overexpression in prostate cancer, the effects of Jazz90 and Jazz167 were investigated in CRPC. They were examined in AR+ (LnCaP) and AR - (DU145 and PC3) prostate cancer cells and non-cancerous (PNT1A) cells. This study explored the cancer cell to normal cell selectivity, HDAC inhibitory potential, and acetylation induction of the novel compounds. We also investigated the cytostatic potential versus the cytotoxic effect of Jazz90, Jazz167, and SAHA in prostate cancer cells to further understand their mechanism of action and clinical potential.

\section{Results}

\subsection{Cytotoxic Potency}

To determine the cytotoxic potential of the novel HDAC inhibitors Jazz90 and Jazz167, a range of prostate cancer cells were treated for $72 \mathrm{~h}$. Jazz90, Jazz167, and SAHA had $\mathrm{EC}_{50}$ values of 2.09, 2.39, and $1.11 \mu \mathrm{M}$ in PC3 cells, respectively (Figure S1 and Table 1). In DU145 cells, $\mathrm{EC}_{50}$ values of 2.50, 6.44, and $0.69 \mu \mathrm{M}$ were obtained for Jazz90, Jazz167, and SAHA, respectively (Table 1$)$. No selectivity of HDAC inhibitors was seen for AR+ (LnCaP) cells, as similar $\mathrm{EC}_{50}$ values of 3.04, 3.36, and $0.61 \mu \mathrm{M}$ were observed for Jazz90, Jazz167 and SAHA, respectively. Although SAHA expressed lower $\mathrm{EC}_{50}$ values in cancer cell lines in comparison to Jazz90 and Jazz167, it had a lower selectivity index (SI) of 1.65 compared to the selectivity indices of 2.93 and 3.50 for Jazz90 and Jazz167 in PC 3 cells (Figure S1 and Table 1). SAHA had the highest SI (3.07), followed by Jazz167 (2.53) and Jazz90 (2.02) in LnCaP cells. SAHA was most active against DU145 cells (2.71), followed by Jazz90 (2.45) and Jazz167 (1.30). The $\mathrm{EC}_{50}$ values in $\mathrm{NIH} 3 \mathrm{~T} 3$, a preneoplastic cell line, were comparable to PNT1A cells, where Jazz167 exhibited a selectivity of 0.50, followed by Jazz90 (0.64) and SAHA (1.33) (Table 1). 
Table 1. Selectivity index of Jazz90 and Jazz167.

\begin{tabular}{|c|c|c|c|c|}
\hline Compound & $\begin{array}{c}\text { Cancer/Preneoplastic } \\
\text { Cell Lines }\end{array}$ & $\begin{array}{l}\mathrm{EC}_{50} \text { Values }(\mu \mathrm{M}) \\
\text { (Cancer Cells) }\end{array}$ & $\begin{array}{l}\text { EC }_{50} \text { Values }(\mu \mathrm{M}) \\
\text { (PNT1A Cells) }\end{array}$ & Selectivity Index ${ }^{1}$ \\
\hline \multirow{4}{*}{ Jazz90 } & PC3 & $2.09 \pm 0.33$ & \multirow[t]{4}{*}{$6.13 \pm 0.74$} & 2.93 \\
\hline & DU145 & $2.50 \pm 0.65$ & & 2.45 \\
\hline & LnCaP & $3.04 \pm 0.93$ & & 2.02 \\
\hline & NIH 3T3 & $3.93 \pm 0.65$ & & 0.64 \\
\hline \multirow{4}{*}{ Jazz167 } & PC3 & $2.39 \pm 0.16^{*}$ & \multirow[t]{4}{*}{$8.36 \pm 0.10$} & 3.50 \\
\hline & DU145 & $6.44 \pm 1.26^{*}$ & & 1.30 \\
\hline & LnCaP & $3.36 \pm 0.71$ & & 2.53 \\
\hline & NIH $3 \mathrm{~T} 3$ & $16.79 \pm 1.77 *$ & & 0.50 \\
\hline \multirow{4}{*}{ SAHA } & PC3 & $1.13 \pm 0.11$ & \multirow[t]{4}{*}{$1.87 \pm 0.21$} & 1.65 \\
\hline & DU145 & $0.69 \pm 0.08$ & & 2.71 \\
\hline & LnCaP & $0.61 \pm 0.08$ & & 3.07 \\
\hline & NIH $3 \mathrm{~T} 3$ & $1.41 \pm 0.21$ & & 1.33 \\
\hline
\end{tabular}

${ }^{1}$ Selectivity index was calculated by dividing the $\mathrm{EC}_{50}$ values in normal PNT1A cells by that in cancer cells. ${ }^{*}$ Significantly different from SAHA, $p<0.05$. Data were analyzed using a one-way ANOVA followed by Bonferroni's post-hoc test.

\subsection{HDAC Inhibition and Cellular Effects on Acetylation of Histone-3 Variant}

To determine if Jazz90 and Jazz167 could inhibit a range of HDACs, HDAC inhibition assays were conducted in nuclear lysates from both HeLa and PC3 cells. Both Jazz90 and Jazz167 exhibited similar HDAC inhibition to SAHA (Figure 2). Jazz90 led to HDAC inhibition of 34 and $45 \%$ at 0.1 and $0.2 \mu \mathrm{M}$, whereas Jazz167 resulted in 38 and 53\% inhibition at 0.1 and $0.2 \mu \mathrm{M}$, respectively, in HeLa cells. SAHA led to HDAC inhibition of 44 and $59 \%$ at 0.1 and $0.2 \mu \mathrm{M}$, respectively, in HeLa cells (Figure 2a). The positive control (trichostatin A (TSA)) led to $80 \%$ HDAC inhibition at a concentration of $0.1 \mu \mathrm{M}$ (Figure 2a). In the PC3 lysate, Jazz90 resulted in inhibition of 58 and 69\% compared to 59 and $64 \%$ inhibition for Jazz167 and 57 and $63 \%$ for SAHA (Figure 2b) at 0.05 and $0.1 \mu \mathrm{M}$, for all compounds, respectively.

To validate the results from HDAC inhibition assays, molecular docking was conducted. The crystal structure of SAHA complexed with HDAC2 (PDB ID: 4LXZ) shows the hydroxamate coordinated to the zinc ion [26]. The hydroxamate coordination is stabilized by hydrogen bonding to histidine-146 and tyrosine-306. Hydrophobic interactions occur between the phenyl ring of phenylalanine-155 and the aliphatic chain in SAHA. An additional hydrogen bond exists between aspartic acid-102 and the amide nitrogen of SAHA (Figure 3a). Jazz 90 was docked 10 times into the ligand binding site of HDAC2 and of those, only 1 pose showed the hydroxamate coordinating to the zinc ion (Figure 3b). Interactions between Jazz90 and HDAC2 were similar to that seen for the crystal structure of the SAHA complex with hydrophobic interactions between the alkyl chain and phenylalanine-155 as well as the phenyl ring and proline-35. Four of the remaining poses resulted in an unexpected binding mode where the pyridinecarbothioamide group coordinated to the zinc ion (Figure 3c). This form of zinc coordination was verified via the Cambridge Structural Database (CCDC) with entry CCDC 1257652 showing coordination to zinc via a pyridinecarbothioamide. The phenyl ring of Jazz 90 lays between phenylalanine- 155 and phenylalanine-210 forming a $\pi$-stacking interaction (Figure $3 c$ ). The remaining poses were similar to the latter orientation; however, the pyridine nitrogen did not coordinate (ring rotated by $180^{\circ}$, not shown) and was therefore dismissed. 
(a)

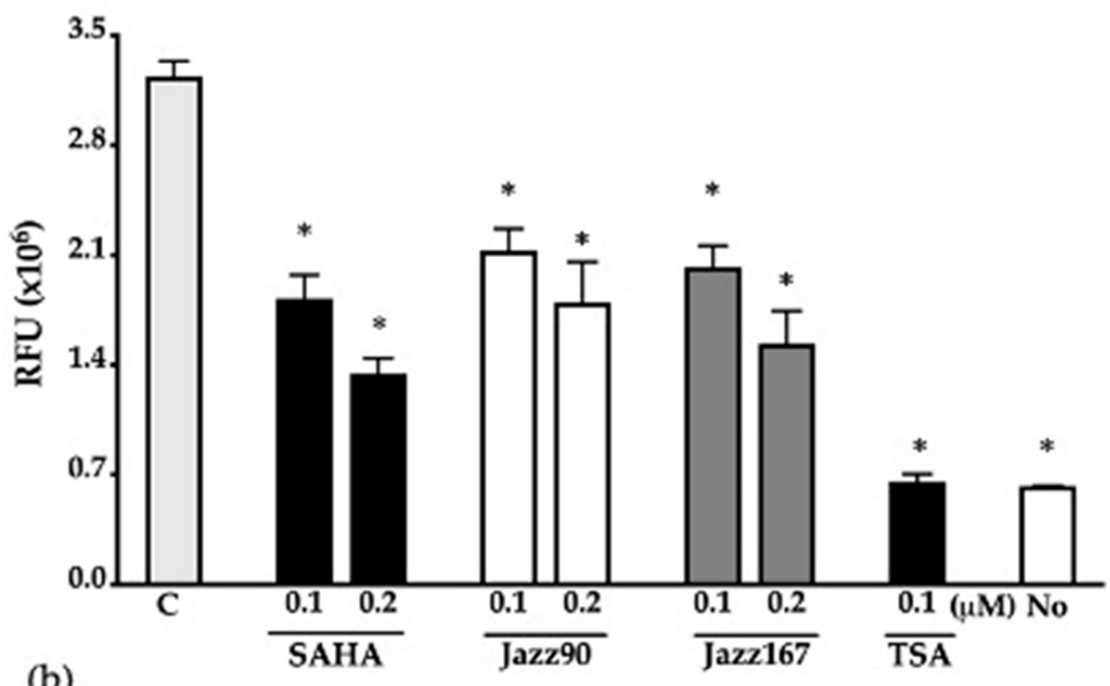

(b)

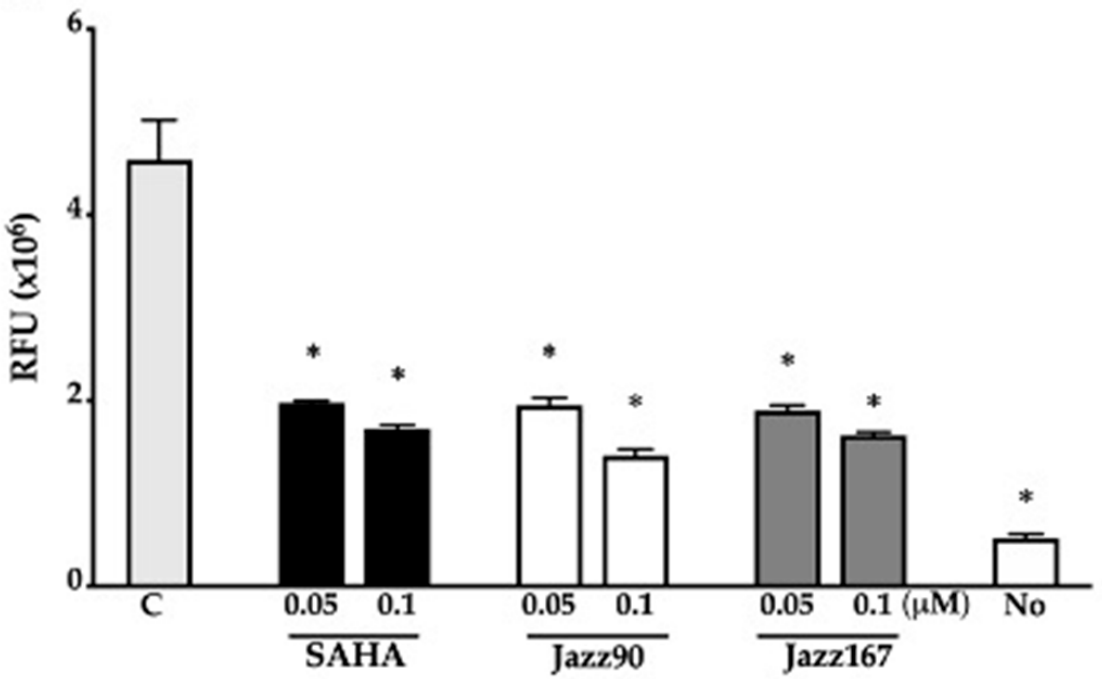

Figure 2. HDAC inhibition elicited by Jazz90 and Jazz167. (a) HeLa nuclear lysates were treated with 0.1 and $0.2 \mu \mathrm{M}$ of Jazz90, Jazz167, and SAHA. TSA $(0.1 \mu \mathrm{M})$ was used as a positive control and a no enzyme control (No) was also used. Vehicle control (C) lysates were treated with $0.5 \%$ DMSO. (b) PC3 nuclear lysates were treated with 0.05 and $0.1 \mu \mathrm{M}$ of SAHA, Jazz90, and Jazz167. Bar graphs represent the relative fluorescence units (RFU) measured after $70 \mathrm{~min}$ of treatment. A two-way ANOVA was conducted followed by Bonferroni's post hoc test. * indicates significant difference to control, $p<0.05$. Images from the kinetic assays are provided in Figures S2 and S3. 


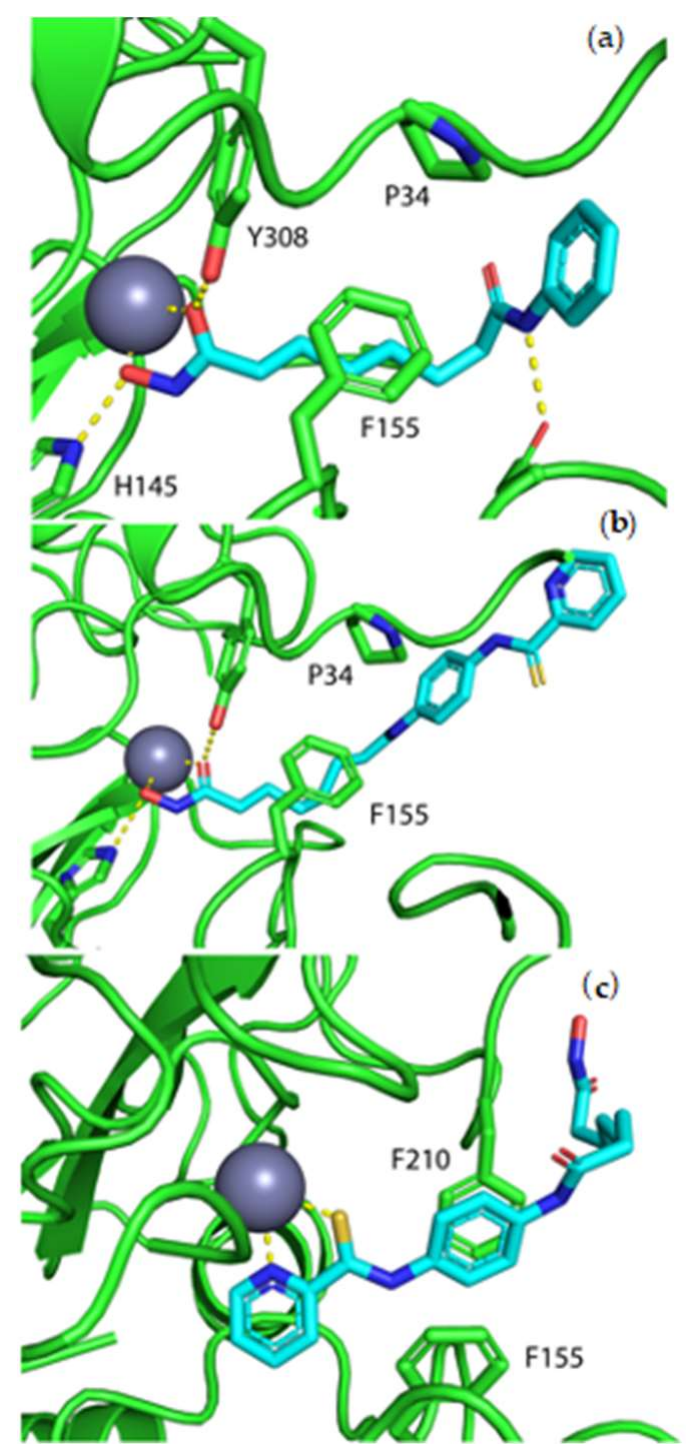

Figure 3. SAHA and Jazz90 binding to HDAC2. Jazz90 was docked into HDAC2 (PDB ID: 4LXZ). (a) Crystal structure of SAHA (cyan) complexed with HDAC2, (b) Jazz90 docked into HDAC2 with hydroxamate coordination to zinc, and (c) Jazz90 docked into HDAC2 with pyridinecarbothioamide coordination. Green ribbons and sticks represent the active site of HDAC2. (Blue atoms = nitrogen, yellow $=$ sulfur, and red $=$ oxygen).

Acetylation of the histone-3 variant was assessed to understand the cellular effects of these compounds on HDAC inhibition. Jazz90 led to a significant 6.24- and 8.22-fold increase in deacetylation levels of histone-3 (H3) at concentrations of 1 and $4 \mu \mathrm{M}$, whereas Jazz167 caused a significant 6.3-fold increase in deacetylation levels of $\mathrm{H} 3$ at a concentration of $4 \mu \mathrm{M}$ in PC3 cells (Figure $4 \mathrm{~b}$ ). For comparison, SAHA treatment resulted in a significant 12.9- and a 15.5-fold increase of acetylated H3 levels (Figure 4b). In contrast to PC3 cells, Jazz90 and Jazz167 failed to increase deacetylation in the DU145 cell line (Figure 4c). As HDAC overexpression is a common occurrence in prostate cancer, lower HDAC expression is seen in PNT1A cells [17]. Therefore, baseline acetylation levels in PNT1A cells are higher, as seen from the immunoblotting experiments. Interestingly, SAHA increased the deacetylation levels by a significant 2.1-fold and a 2.6-fold in PNT1A cells compared to the vehicle control (0.56 acetyl-H3/ $\beta$-tubulin), whereas Jazz90 and Jazz167 did not induce significant acetylation (Figure $4 \mathrm{~d}$ ). 
(a) C SAHA Jazz90 Jazz167 $\begin{array}{lllllll}1 & 4 & 1 & 4 & 1 & 4 & (\mu \mathrm{M})\end{array}$
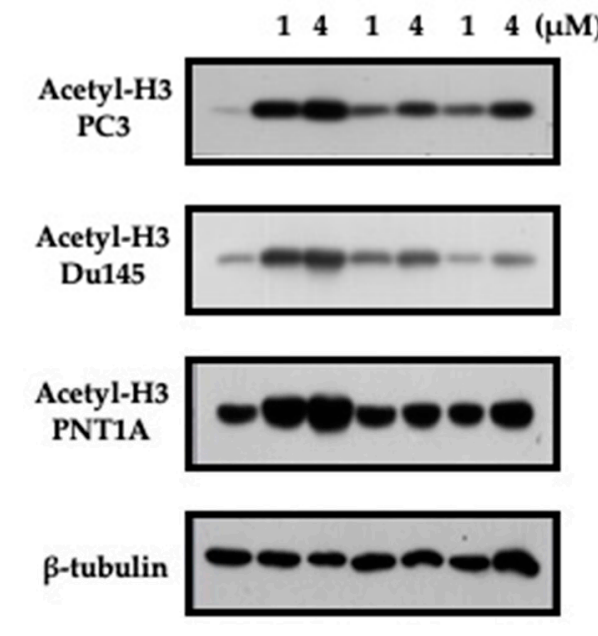

(c)

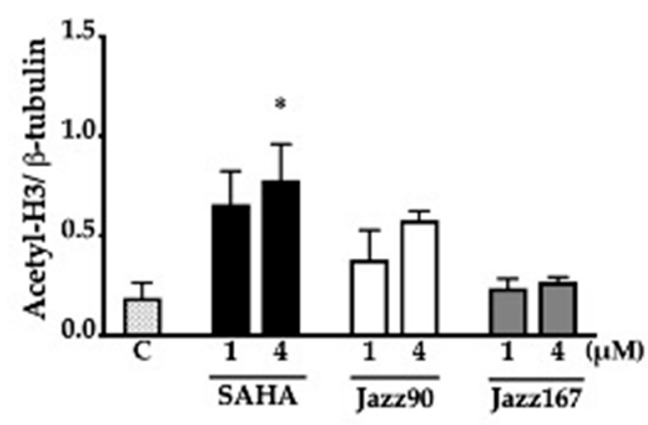

(b)

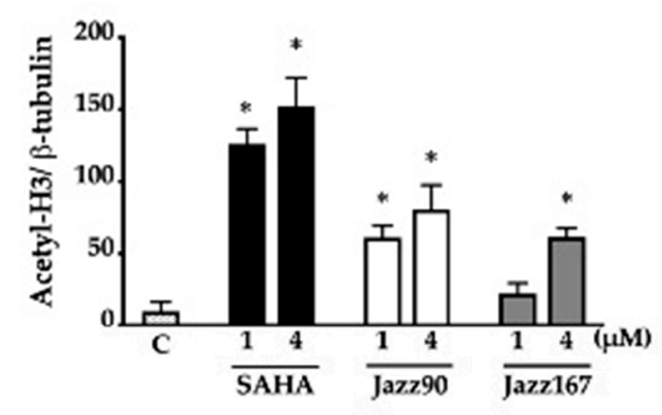

(d)

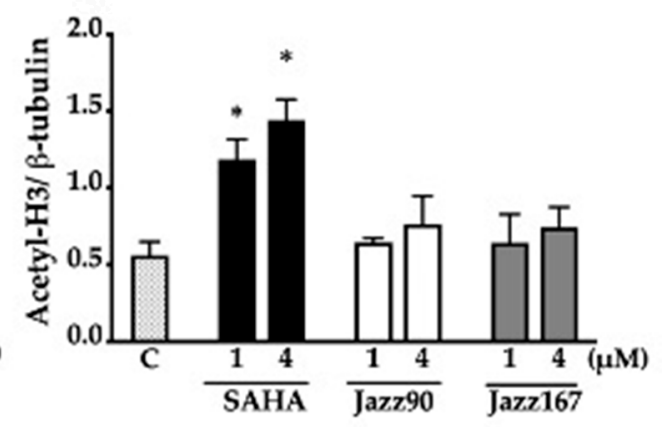

Figure 4. Acetylation levels of CRPC (PC3 and DU145) and normal prostate (PNT1A) cells after treatment at concentrations of 1 and $4 \mu \mathrm{M}$ of SAHA, Jazz90 and Jazz167. Vehicle control cells (C) were treated with 0.5\% DMSO. Cells were harvested $24 \mathrm{~h}$ after treatment. (a) Representative Western blots for acetyl-H3 and $\beta$-tubulin (loading control) are shown for each of the cell lines. Scanning densitometry of Western blots for (b) PC3, (c) DU145, and (d) PNT1A cells. Bars represent the mean \pm S.E.M. from three independent experiments. Data were analyzed using one-way ANOVA followed by Bonferroni's post hoc test; * indicates significant increases relative to the control, $p<0.05$.

\subsection{Compound-Mediated Cytostatic or Cytotoxic Mechanisms}

Time-course analysis was conducted to determine if Jazz 90 and Jazz167 were cytostatic. Jazz90 and Jazz167 led to 2.07- and 2.74-fold significant increases in the number of PC3 cells after $72 \mathrm{~h}$ at $4 \times \mathrm{EC}_{50}$ values compared to time zero (Figure $5 \mathrm{~b}, \mathrm{c}$ ). Similar results were obtained for SAHA, which led to a 1.82-fold increase in PC3 cell number at $4 \times \mathrm{EC}_{50}$ value (Figure 5a). Interestingly, a similar increase in cell number was seen until $48 \mathrm{~h}$ for all treatment conditions (Figure 5). After this point, cell numbers reduced by 17, 10, and $30 \%$ in response to treatment with $4 \times \mathrm{EC}_{50}$ concentrations of Jazz90, Jazz167, and SAHA, whereas the control cells increased by $49 \%$ from 48 to $60 \mathrm{~h}$ (Figure 5). In DU145 cells, SAHA, Jazz90 and Jazz167 led to 1.92-, 1.69-, and 2.02-fold increases in cell number at $1 \times \mathrm{EC}_{50}$ values, respectively. In contrast, no significant difference in cell number was seen between compound treatments at $4 \times \mathrm{EC}_{50}$ values over time in DU145 cells (Figure 5). 
PC3

(a)

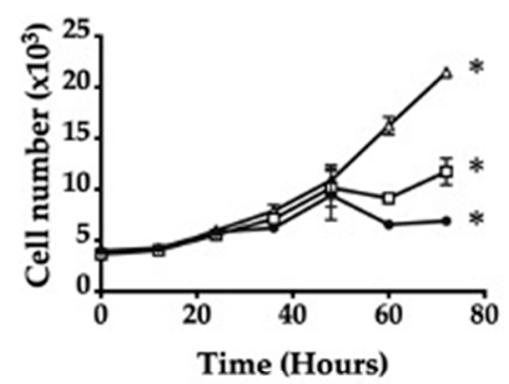

(b)

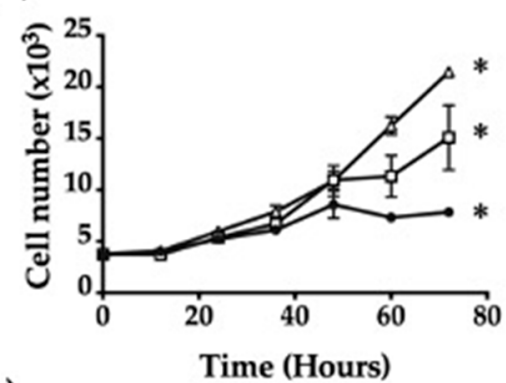

(c)

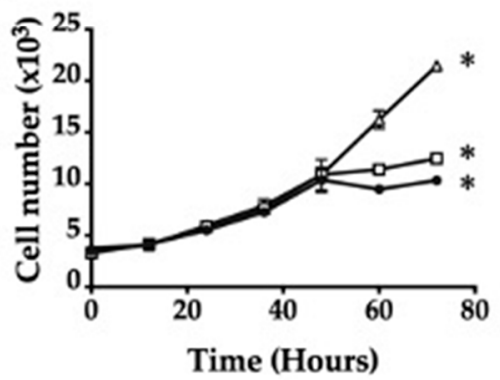

(d)

\section{DU145}

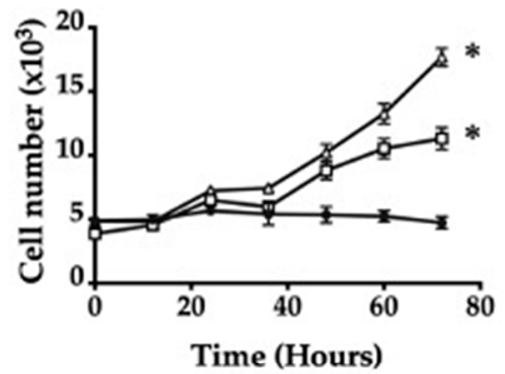

(e)

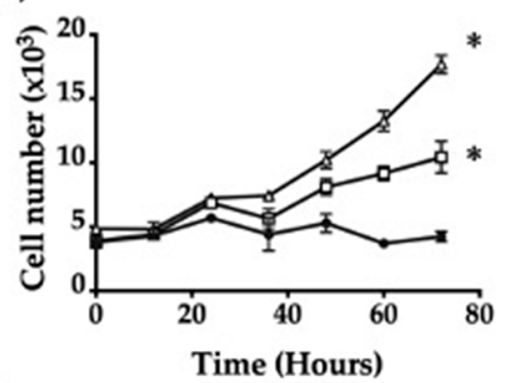

(f)

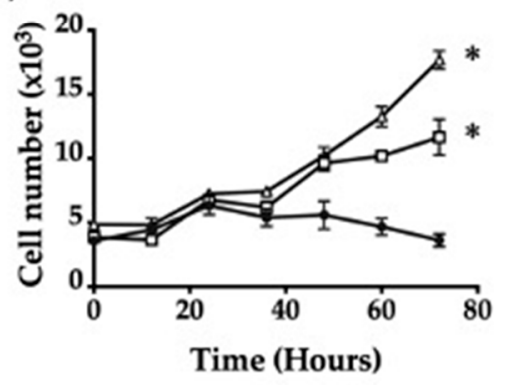

$-\Delta-$ Control

Figure 5. Time-course cytotoxicity analysis in prostate cancer cells. PC3 cells were treated with (a) SAHA, (b) Jazz90, and (c) Jazz167, and DU145 cells were treated with (d) SAHA, (e) Jazz90, and (f) Jazz167 at concentrations of $1 \times \mathrm{EC}_{50}$ and $4 \times \mathrm{EC}_{50}$ for $0-72 \mathrm{~h}$. Control cells were treated with $0.5 \%$ DMSO. Cell number was measured using the SRB assay. Symbols indicate cell number \pm S.E.M from three independent experiments performed in triplicate. Data were analyzed using a two-way ANOVA coupled with Bonferroni's post hoc test; * indicates significant differences compared to the start of the experiment, $p<0.05$.

These results imply that Jazz90 and Jazz167 have a cytostatic effect in DU145 cells at $4 \times \mathrm{EC}_{50}$ values, but not in PC3 cells. To understand the mechanism of action of these compounds further, cell cycle and apoptotic analyses were conducted. Jazz90 $(6 \mu \mathrm{M})$ elicited a significant increase in $\mathrm{G}_{0} / \mathrm{G}_{1}$ cells by 23 and $14 \%$ at 48 and $60 \mathrm{~h}$, respectively (Figure $6 \mathrm{~b}, \mathrm{c}$ ), compared to SAHA, which increased the number of cells in the $\mathrm{G}_{2} / \mathrm{M}$ phase by 53 and $56 \%$ at 6 and $8 \mu \mathrm{M}$, respectively, at $24 \mathrm{~h}$ (Figure 6a). At $48 \mathrm{~h}$, SAHA induced a significant $\mathrm{G}_{2} / \mathrm{M}$ phase arrest at $8 \mu \mathrm{M}$. At $60 \mathrm{~h}$, no significant changes were observed in response to SAHA. This shows that the effects of Jazz 90 are more persistent than SAHA. For DU145, significant differences in $\mathrm{G}_{0} / \mathrm{G}_{1}$ arrest were observed between all treatments and control at $48 \mathrm{~h}$ (Figure 7). 
(a) 24 hours

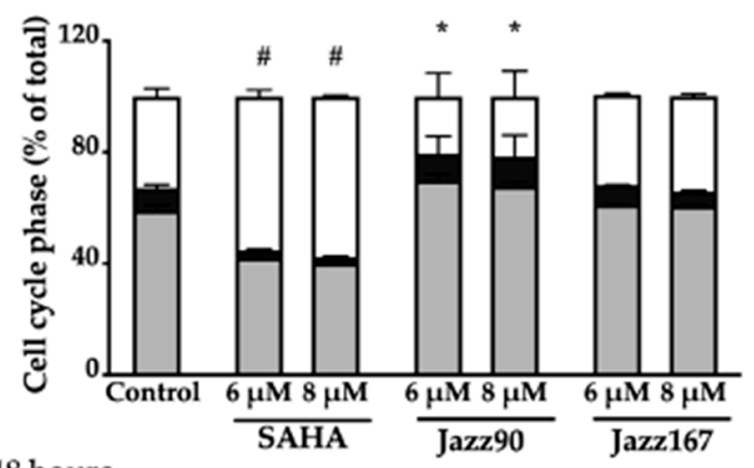

(b) 48 hours

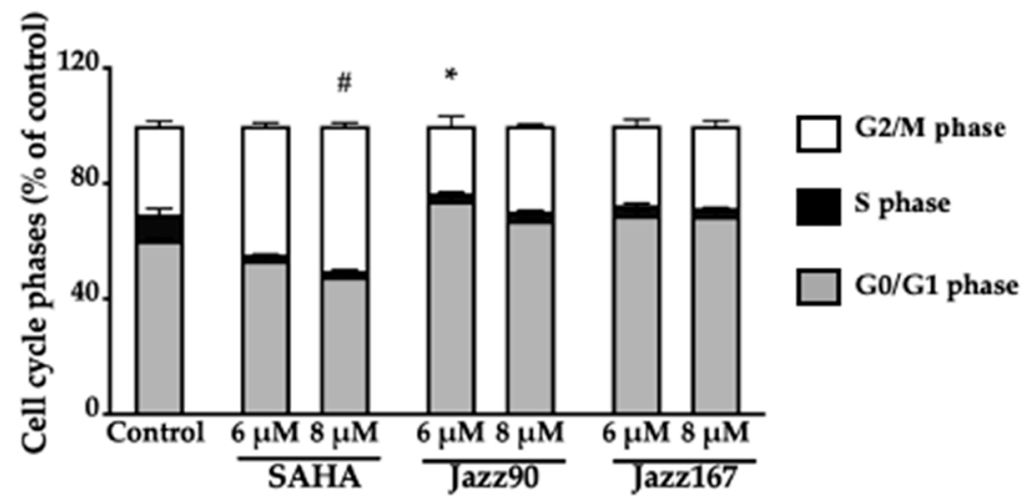

(c) 60 hours

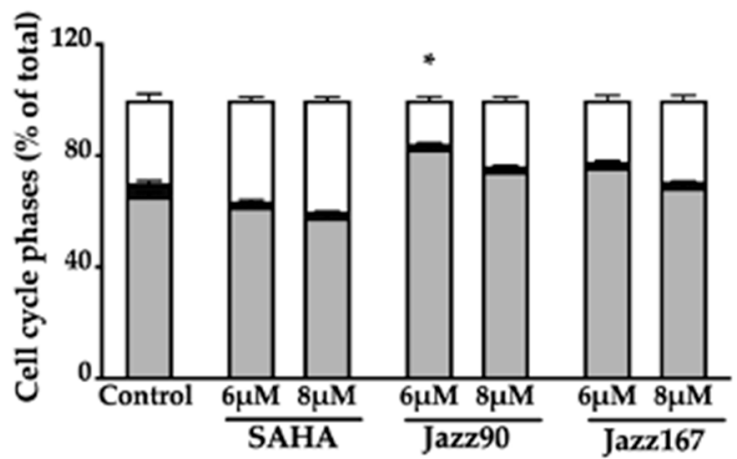

Figure 6. Cell cycle phases of PC3 cells at different time-points. PC3 cells were treated with SAHA, Jazz90 and Jazz167 at concentrations of 6 and $8 \mu \mathrm{M}$ for (a) 24, (b) 48, and (c) $60 \mathrm{~h}$. Vehicle control cells were treated with $0.5 \%$ DMSO. Cell cycle phases were measured using flow cytometry. Bars represent the mean \pm S.E.M. of the percentage of cells in each of the cell cycle phases $\left(G_{0} / G_{1}, S\right.$ and $\mathrm{G}_{2} / \mathrm{M}$ phases) from three independent experiments. Data were analyzed using a two-way ANOVA coupled with Bonferroni's post hoc test. \# indicates $\mathrm{G}_{2} / \mathrm{M}$ significantly different from the control, $p<0.05$; ${ }^{\text {indicates }} \mathrm{G}_{0} / \mathrm{G}_{1}$ significantly different from the control, $p<0.05$. 
(a)

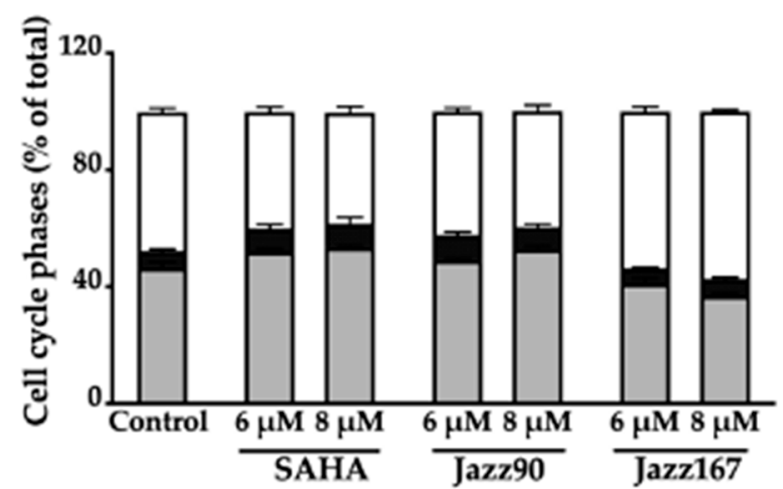

(b)

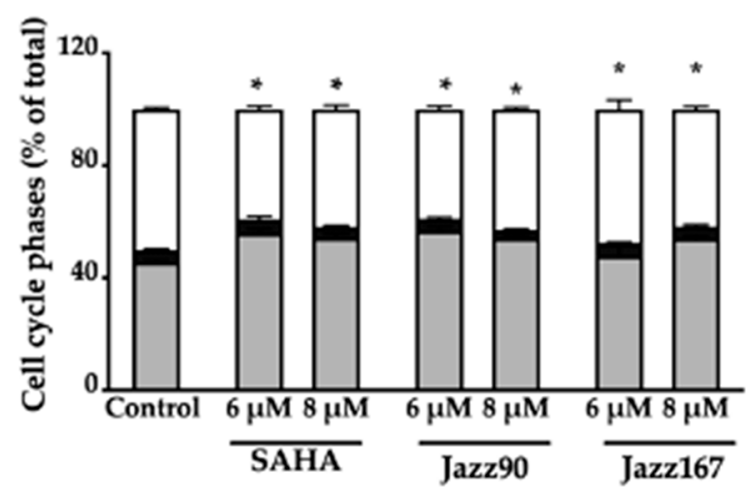

S phase

7. Cell cycle phases of DU145 cells at different time-points. DU145 cells were treated with SAHA, Jazz90 and Jazz167 at concentrations of 6 and $8 \mu \mathrm{M}$ for (a) 24 and (b) $48 \mathrm{~h}$. Vehicle control cells were treated with $0.5 \%$ DMSO. Cell cycle phases were measured using flow cytometry. Bars represent the mean \pm S.E.M. of percentage of cells in each of the cell cycle phases $\left(G_{0} / G_{1}, S\right.$, and $\mathrm{G}_{2} / \mathrm{M}$ phases) from three independent experiments. Data were analyzed using a two-way ANOVA coupled with Bonferroni's post hoc test. * indicates $\mathrm{G}_{0} / \mathrm{G}_{1}$ significantly different from the control, $p<0.05$.

The cell cycle profile was further validated by determining changes in cell cycle checkpoint proteins, cyclins and cyclin-dependent kinase (CDK) inhibitors. At $24 \mathrm{~h}$, a significant reduction of 35 and $53 \%$ in cyclin D levels compared to the control was seen in PC 3 cells in response to Jazz 90 at concentrations of 6 and $8 \mu \mathrm{M}$, respectively (Figure 8b). Similarly, SAHA showed a 35 and $69 \%$ decrease at the same concentrations; however, no significant decreases were observed for cyclin B (Figure 8c). Furthermore, CDK inhibitors were upregulated in response to compound treatment. Specifically, Jazz90 significantly increased p 21 by $286 \%$ at a concentration of $8 \mu \mathrm{M}$ (Figure $8 \mathrm{~d}$ ). However, Jazz167 did not change p21 levels (Figure 8d). Significant increases of 445 and 345\% in p27kip1 were seen in response to Jazz90 and Jazz167 at a concentration of $8 \mu \mathrm{M}$. SAHA, in comparison, led to a significant increase of 366 and $480 \%$ in p27kip1 at concentrations of 6 and $8 \mu \mathrm{M}$ (Figure 8e). A similar profile was obtained in DU145 cells, except that all compounds were more effective at inhibiting cyclin D and less effective at modulating p27kip1 in this cell line (Figure 9b). 
(a)

Cyclin D

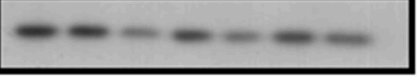

Cyclin B

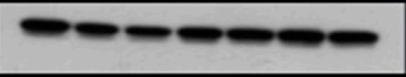

P27Kip1

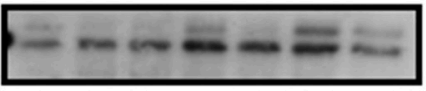

P21

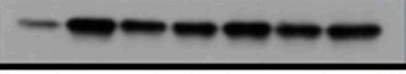

$\beta$-tubulin

(b)

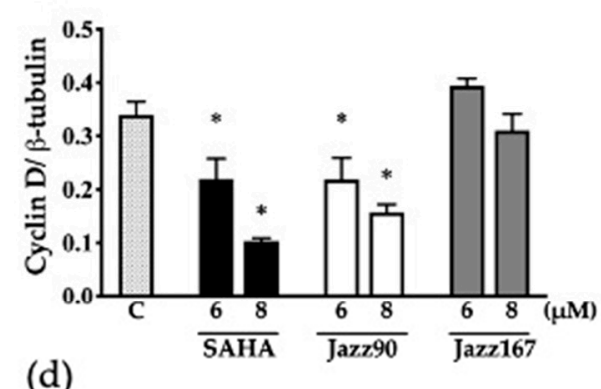

(d)

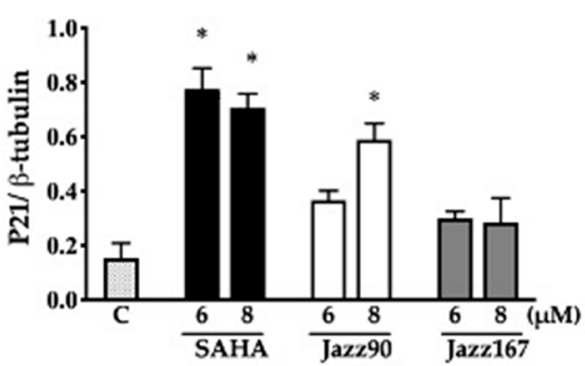

(c)

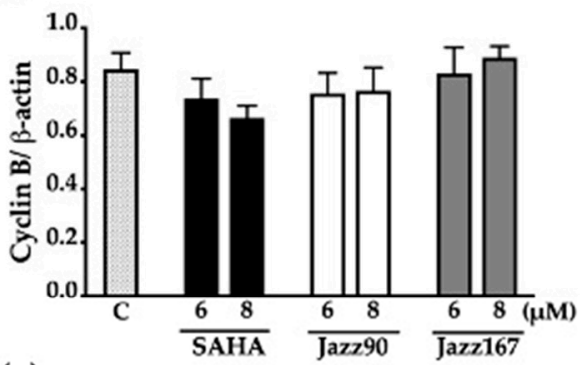

(e)

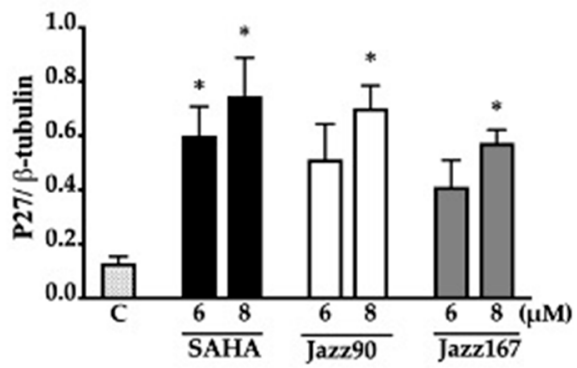

Figure 8. Cell cycle protein expression in PC3 cells. Cyclin D, cyclin B, p27kip1 and p21 levels were assessed in response to SAHA, Jazz90, and Jazz167 in PC3 cells at concentrations of 6 and $8 \mu \mathrm{M}$ for $24 \mathrm{~h}$. Vehicle control cells (C) were treated with $0.5 \%$ DMSO. Cell lysates were analyzed using Western blotting and $\beta$-tubulin was used as the loading control. (a) Representative blots for each of the proteins. Scanning densitometry graphs for (b) cyclin D, (c) cyclin B, (d) p21, and (e) p27kip1 are depicted. Bars represent the means \pm S.E.M. from three independent experiments. Data were analyzed using a one-way ANOVA coupled with Bonferroni's post hoc test; * indicates significant differences relative to the control, $p<0.05$. 
(a)

Cyclin D

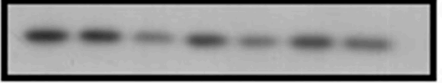

Cyclin B

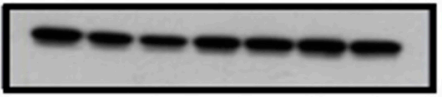

P27Kip1

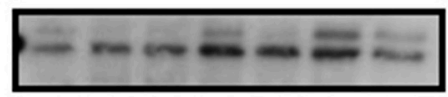

P21

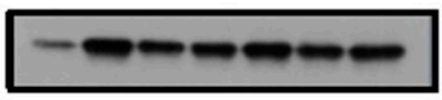

$\beta$-tubulin

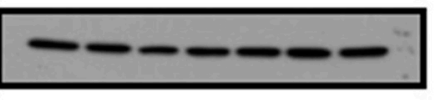

(b)

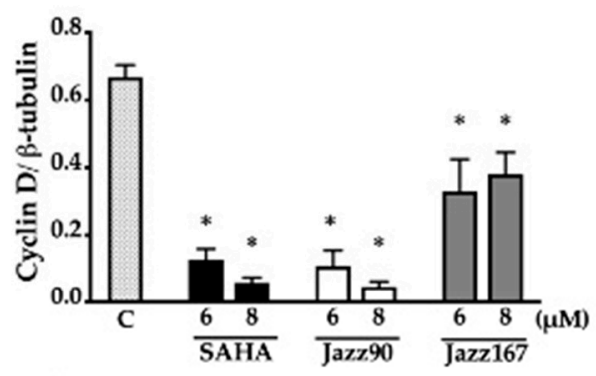

(d)

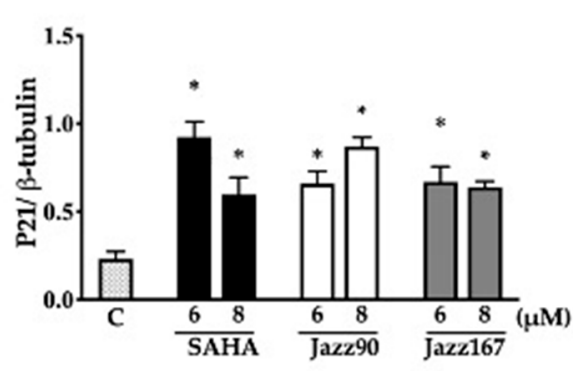

(c)

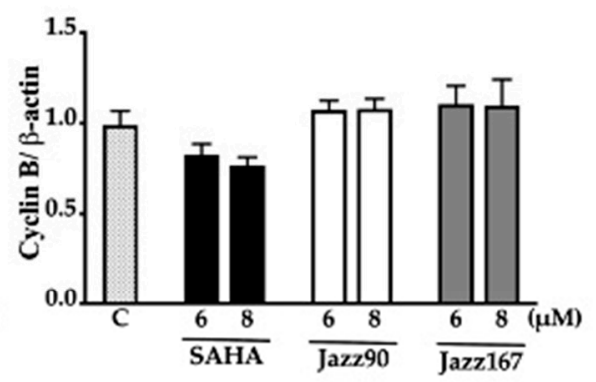

(e)

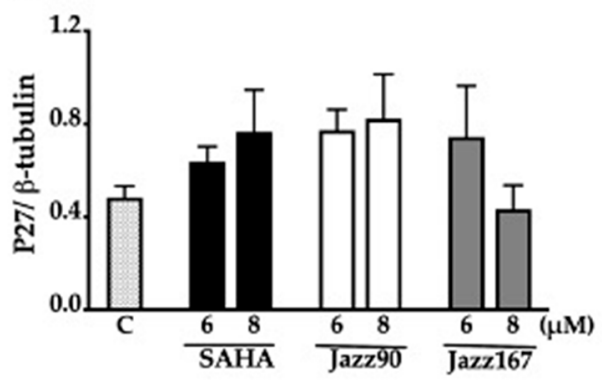

Figure 9. Cell cycle protein expression in Du145 cells. Cyclin D, cyclin B, p27kip1 and p21 levels were assessed in response to SAHA, Jazz90 and Jazz167 in PC 3 cells at concentrations of 6 and $8 \mu \mathrm{M}$ for $24 \mathrm{~h}$. Vehicle control cells (C) were treated with $0.5 \%$ DMSO. Cell lysates were analyzed using Western blotting and $\beta$-tubulin was used as the loading control. (a) Representative blots for each of the proteins. Scanning densitometry graphs for (b) cyclin D, (c) cyclin B, (d) p21, and (e) p27kip1 are depicted. Bars represent the means \pm S.E.M. from three independent experiments. Data were analyzed using a one-way ANOVA coupled with Bonferroni's post hoc test; * indicates significant differences relative to the control, $p<0.05$.

Apoptosis induction was examined to determine if this was associated with the mechanism of action of the compounds. Minimal apoptosis (less than $8 \%$ ) was seen in response to Jazz90, Jazz167, and SAHA in PC3 cells (Figure 9). No significant changes were observed in the expression of the antiapoptotic protein, bcl-2, between controls and compound treatments at $48 \mathrm{~h}$ in PC3 cells (Figure S9). Furthermore, necrosis was minimal for Jazz90 and Jazz167, but it peaked at 14 and 18\% following treatment with 6 and $8 \mu \mathrm{M}$ of SAHA (Figure 10). In DU145 cells, less than $2 \%$ of the cells were apoptotic at 24 and $48 \mathrm{~h}$ (Figure S9), and the percentage of necrotic cells did not exceed 11\% for Jazz90, Jazz167, and 
SAHA (Figure S9b). No significant differences were observed for bcl-2 between control and compound treatments at $48 \mathrm{~h}$ in DU145 cells (Figure S10).

(a)

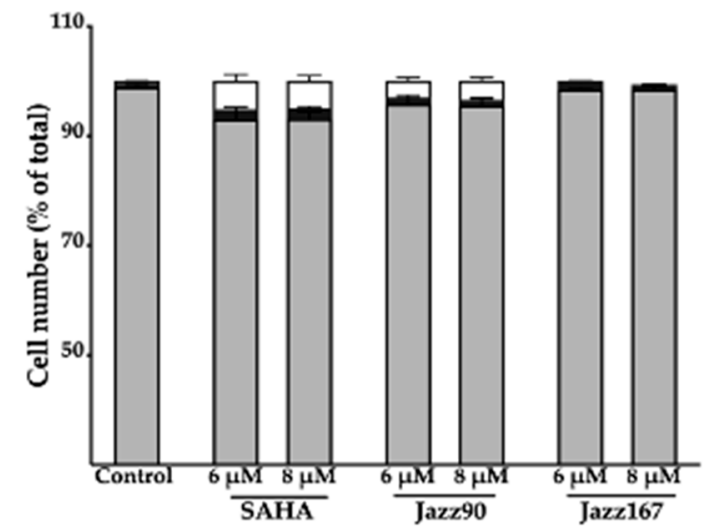

(b)
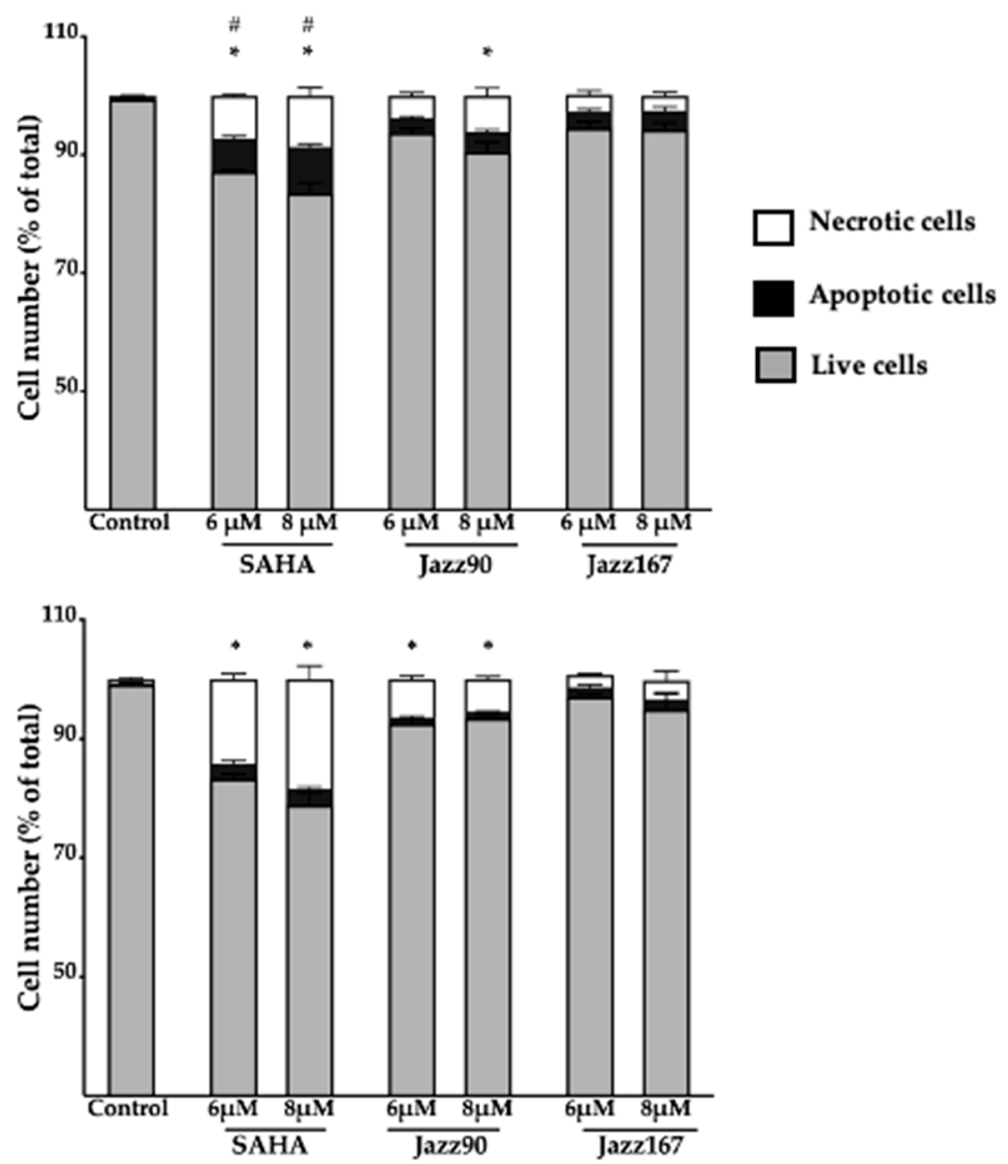

Figure 10. Analysis of apoptosis and necrosis in PC3 cells. Cells were treated with SAHA, Jazz90 and Jazz167 at concentrations of 6 and $8 \mu \mathrm{M}$. Vehicle control cells were treated with $0.5 \%$ DMSO. Cells were harvested at (a) 24, (b) 48, and (c) 60 h, after which the cells were stained with Annexin V and PI, and analyzed by flow cytometry. Bars represent the mean proportion of live, apoptotic and necrotic cells \pm S.E.M. from three independent experiments. Data were analyzed using a two-way ANOVA coupled with Bonferroni's post-hoc test; * indicates significant differences in necrotic cells relative to the control, $p<0.05$; \# indicates significant differences in apoptotic cells relative to the control, $p<0.05$.

\subsection{Compound Withdrawal Effects}

As the previous set of experiments showed a minimal level of apoptosis and necrosis, the persistent effects of the compounds were examined by withdrawing them and allowing 
the cells to grow for an additional $72 \mathrm{~h}$. In PC3 cells, no significant differences in cell number over time was found for all treatments, while vehicle control cells significantly increased (Figure S11a-c). However, DU145 cells significantly increased after $72 \mathrm{~h}$ of withdrawal of $1 \times \mathrm{EC}_{50}$ values of SAHA, Jazz90 and Jazz167 (Figure S11d-f).

\section{Discussion}

Jazz90 and its organorhodium derivative, Jazz167, have been identified as potent HDAC1, 6, and 8 inhibitors [22]. In this study, we investigated their anticancer potential in prostate cancer cell lines. Thioamides can react with nucleophiles and electrophiles and they also have an affinity for metal binding [27]. Given that HDACs feature a zinc (II) ion in the active site, ligand docking predicted that Jazz90 can bind to HDACs via either the hydroxamic acid or pyridinecarbothioamide moiety. Pyridinecarbothioamides have not been shown to have metalloenzyme inhibitory activity, and further assessment of the structure-activity relationship via replacing the hydroxamate acid in Jazz90 shall give a better insight into the potential of pyridine carbothioamide for zinc coordination in HDAC. Using the static model of ligand docking, similar hydrogen bond and hydrophobic interactions were seen in response to Jazz90 and SAHA. This was supported by their equipotent inhibition of HDAC activity in PC3 cells. Considering HDACs as potential targets for the pyridinecarbothioamide compounds, it is possible that Jazz90 and Jazz167 feature different binding modes to the Zn(II) ion. While Jazz167 resembles the HDAC inhibition of SAHA through targeting the Zn(II) ion with its hydroxamate moiety, Jazz90 may also bind through the pyridinecarbothioamide coordination motif (sulfur and nitrogen) to the $\mathrm{Zn}$ ion, as demonstrated by docking investigations. The Rh moiety to in Jazz167 impacts its physicochemical properties, including the lipophilicity and aqueous solubility, which may impact the anticancer potency.

Clinical data suggest that normal prostate epithelial cells have a lower HDAC activity, whereas PC3, LnCAP and DU145 cells have higher HDAC activity [17]. Jazz90 and Jazz167 are more cytotoxic against AR-null prostate cancer cells (PC3 and DU145) compared to normal prostate epithelial cells (PNT1A). They also have a higher selectivity index in PC 3 cells in comparison to SAHA. These results are further supported by the significant inhibition of deacetylation of histone-3 in response to SAHA in PNT1A cells. In a previous study, SAHA inhibited deacetylation of histone- 3 at concentrations of 2.5 and $5 \mu \mathrm{M}$ [28]. Results from the selectivity index of Jazz90 and Jazz167 correlate with the levels of HDACs in LnCaP, PC3, and DU145 cells. This might explain the higher selectivity of Jazz90 and Jazz167 toward the AR-null (PC3 and DU145) cells in comparison to AR+ (LnCaP) cells. The cytotoxicity of SAHA in this study was comparable to previous studies. PC 3 cells are relatively resistant to SAHA in comparison to DU145 and LnCaP cells [29]. The resistance can be attributed to the overexpression of bcl-2, an antiapoptotic protein in the PC3 cell line, whereas DU145 cells are reported to either lack or have a reduced expression of bcl-2 levels [29].

This study also aimed to define the cytostatic versus cytotoxic action of novel anticancer agents. Cell number, cell cycle phase changes, and apoptosis induction were used to determine this action. Previously, none of the studies associated with HDAC inhibitors have examined all of these parameters. Results from the time course analysis of the activity of SAHA, Jazz90, and Jazz167 in cells suggested that the compounds have a cytostatic action. Another reason for conducting a time-course analysis was to investigate an upregulation of resistance mechanisms. HDAC inhibitors have upregulated P-glycoproteins in colorectal cancer cell lines as early as $24 \mathrm{~h}$ after treatment $[30,31]$. However, no switch from negative to positive growth gradients occurred, which would have been observed if the compounds were being effluxed out of the cell. In fact, the opposite occurred in PC 3 cells at $48 \mathrm{~h}$. HDAC inhibitors can have different efficacies for different HDAC isoenzymes at different concentrations. A study conducted by Tang and colleagues showed that ACY-1215, despite being a HDAC6 inhibitor, display cross-selectivity to HDAC1 at higher concentrations [32]. Saturation of a HDAC isoenzyme can result in the binding of HDAC 
inhibitors to other isoenzymes. These results could be determined using posttranslational modification-based proteomic profiling using shotgun mass spectrometry.

Cell cycle arrest was observed in response to all three compounds, and the profiles were linked to a reduction in cyclin D1 and an increase in p21 and p27kip1. Minimal apoptosis induction $(<3 \%)$ was observed in DU145 and PC3 cells, whereas necrosis elicited by Jazz 90 and Jazz167 was less than $5 \%$. In contrast, SAHA at $8 \mu \mathrm{M}$ caused $13 \%$ of cells to undergo necrosis after $60 \mathrm{~h}$, while $10 \%$ of DU145 cells were necrotic at $48 \mathrm{~h}$. Similar results were observed in response to SAHA in previous studies. SAHA led to a $G_{2} / M$ phase arrest in PC 3 cells and a $G_{0} / G_{1}$ phase arrest in DU145 cells $[29,33]$. Furthermore, Patra and colleagues (2013) showed an upregulation of p21 and p27 in response to SAHA in PC3 and DU145 cells [29]. Low rates of apoptosis of 14 and 17\% were seen in DU145 and PC3 cells, respectively, in response to $9 \mu \mathrm{M}$ of SAHA [34].

One of the reasons for the cell-specific effects may be that PC3 is PTEN- and p53negative and DU145 have a loss-of-function mutated p53 [35-37]. Absence of PTEN and p53 is linked to proliferation and survival pathways in PC3 and DU145 cells. Another commonly mutated pathway in prostate cancer cells is the Erk protein, which following phosphorylation, triggers proliferation and survival. Effects of Jazz90 and Jazz167 are most likely mediated via reduction of the Erk phosphorylation, as seen in previous studies [6,38-40]. Overall, the results indicate that Jazz90 and Jazz167 can be classified as cytostatic. Cytostatic compounds have a role as they can lower the required doses of cytotoxic drugs when used in combination, which can reduce side effects [41]. Cytostatic drugs can also make cells more detectable by immune cells [42]. Furthermore, pyridinecarbothioamides have been shown to have metalloenzyme inhibitory activity, and further assessment of structure-activity relationships via replacing the hydroxamic acid moiety in Jazz90 will give a better insight into the potential of pyridinecarbothioamide-zinc coordination to induce biological effects. Thus, Jazz90 and Jazz167 should undergo further examination, including in animal models for toxicity and efficacy.

\section{Materials and Methods}

\subsection{Materials}

Prostate cancer cell lines, AR- (PC3 and DU145 cells) and AR+ (LnCAP cells) and mouse embryonic fibroblasts (NIH 3T3 cells) were obtained from American Type Culture Collection (Manassas, VA, USA). The epithelial prostate cell line immortalized with SV40 (PNT1A) was gifted from the Department of Anatomy, University of Otago. Primary antibodies to acetyl H3, cyclin D, cyclin B, p21, p27kip1, and bcl-2 were purchased from Cell Signaling Technology (Danvers, MA, USA). $\beta$-tubulin, $\beta$-actin, Dulbecco's modified Eagle's medium (DMEM) nutrient mixture Ham's F-12, sulforhodamine B salt and propidium iodide (PI) were purchased from Sigma-Aldrich (Auckland, New Zealand). Acrylamide, bisacrylamide, sodium dodecylsulfate and PVDF membrane were purchased from Bio-Rad Laboratories (Hercules, CA, USA). Complete mini-EDTA-free protease inhibitor was purchased from Roche Diagnostics Corporation (Mannheim, Germany). Annexin V APC was obtained from BD Pharmingen (San Jose, CA, USA). FxCycle PI RNase staining solutions were ordered from Life Technologies (Christchurch, New Zealand). The Histone Deacetylase (HDAC) Activity Assay Kit (Fluorometric) was purchased from Abcam (Melbourne, Australia). Jazz90 and Jazz167 were synthesized as previously described [23]. SAHA was obtained from AK Scientific (Union City, CA, USA).

\subsection{Cell Maintenance}

PC3 and DU145 cells were maintained in 5\% DMEM/Ham's F12 supplemented with 100 units/mL penicillin, 100 units $/ \mathrm{mL}$ of streptomycin and $2.2 \mathrm{~g} / \mathrm{L}$ of $\mathrm{NaHCO}_{3}$, whereas LnCAP and PNT1A cells were cultured in RPMI640 media with 10\% FBS, 100 units / mL penicillin. All cells were maintained at $37{ }^{\circ} \mathrm{C}$ in a humidified atmosphere of $5 \% \mathrm{CO}_{2}$. 


\subsection{Cytotoxicity Assays and Time-Course Analysis}

PC3 $\left(4 \times 10^{3}\right.$ cells/well $)$, DU145 $\left(5 \times 10^{3}\right.$ cells/well $), \operatorname{LnCAP~}\left(1 \times 10^{4}\right.$ cells/well $)$, PNT1A $\left(1 \times 10^{4}\right.$ cells /well), and NIH 3T3 cells $\left(3.5 \times 10^{3}\right.$ cells/well $)$ were plated in 96-well plates. After $24 \mathrm{~h}$, the cells were treated with Jazz90, Jazz167, and SAHA at concentrations ranging from 0 to $150 \mu \mathrm{M}$. Vehicle control cells were treated with $0.5 \%$ DMSO. The cells were fixed using $10 \%$ trichloroacetic acid (TCA) after $72 \mathrm{~h}$. The sulforhodamine B (SRB) assay was then used to determine the cell number as previously described [43]. EC 50 values were determined by nonlinear regression using Prism 9 software. Three independent experiments were carried out in triplicate.

\subsection{HDAC Inhibition}

The Histone Deacetylase Activity Assay Kit (Fluorometric; ab156064) was used to measure HDAC inhibition. Corning black, 96-well plates were used and the following groups were run: no enzyme control, solvent control, and $0.05,0.1$, and $0.2 \mu \mathrm{M}$ of Jazz90, Jazz167, and SAHA. Trichostatin A (TSA) was used as a positive control as provided with the kit. The principle of the assay relies on the deacetylation of the fluoro-substrate peptide by HDACs. Fluoro-deacetylated peptides are produced in the process, which can then be hydrolyzed by lysyl endopeptidases into lysine and 7-amino-4-methylcoumarin (AMC). AMC leads to an increase in fluorescence intensity. The experiment was run for $70 \mathrm{~min}$ and readings were taken every $2 \mathrm{~min}$ using a SpectraMax i3X fluorimeter (San Jose, CA, USA). The fluorescence intensity was read at an excitation/emission wavelength of $360 \mathrm{~nm} / 450 \mathrm{~nm}$. Three independent experiments were carried out using HeLa and PC3 nuclear lysates.

\subsection{HDAC Docking}

Jazz90 was drawn using Avogadro, after which the energy of the geometry was optimized. The structure of HDAC2 complexed with SAHA (PDB ID: 4LXZ) was obtained from the Research Collaboratory for Structural Bioinformatics (RCSB) Protein Data Bank [26]. Molecular docking was carried out using GOLD software (Cambridge Crystallographic Data Centre, Cambridge, UK). The binding site was defined as within $8 \AA$ and a metal distance constraint was set to a distance of $3.5 \AA$. Jazz 90 was then docked onto the crystal structure and was assessed for its binding orientation.

\subsection{Preparation of Sample Lysates for Western Blotting}

PC3 and DU145 cells were seeded in $100 \times 20 \mathrm{~mm}$ Petri dishes at $1 \times 10^{6}$ and $1.5 \times 10^{6}$ cells per dish, respectively, with $10 \mathrm{~mL}$ of DMEM/HamF12 supplemented with $5 \%$ FBS and $100 \mathrm{U} / \mathrm{mL}$ penicillin, $100 \mu \mathrm{g} / \mathrm{mL}$ streptomycin and $2.2 \mathrm{~g} / \mathrm{L} \mathrm{NaHCO}$. PNT1A cells were seeded at $2 \times 10^{6}$ cells with $10 \mathrm{~mL}$ of RPMI640 media with $10 \%$ FBS and 100 units / $\mathrm{mL}$ penicillin. Cells were treated after $24 \mathrm{~h}$ with $1,4,6$, and $8 \mu \mathrm{M}$ of SAHA, Jazz90 and Jazz167. At the end of the treatment, whole cell lysates were obtained. The protein concentration of these lysates was determined using the bicinchoninic acid method [44].

\subsection{Western Blotting}

Samples containing $10 \mu \mathrm{g}$ of protein from cellular, nuclear and cytoplasmic extractions were resolved using SDS-PAGE at $100 \mathrm{~V}$. After the sample ran down to the bottom of the gel, the membrane was removed and transferred into the transfer buffer. A sandwich containing equilibrated fiber pad and blotting paper and an activated membrane was made in cassettes. To stop the apparatus from overheating, ice was placed in the apparatus. A voltage of $100 \mathrm{~V}$ was set, and the transfer process was carried out for $90 \mathrm{~min}$. The membrane was blocked with BSA blocking buffer $1 \times$, followed by a primary antibody incubation (acetyl$\mathrm{H} 3$, cyclin D, cyclin B, p21, p27kip1, bcl-2, $\beta$-tubulin, and $\beta$-actin) overnight, after which the membrane was washed six times with TBST and incubated with secondary antibody for a period of one hour. After six further washes with TBS, chemiluminescent solutions were then added to the membrane, and X-ray films were exposed to the membrane, after which 
the films were developed. The films were analyzed using a BioRad GS710 densitometer (Hercules, CA, USA), and the protein density was calculated as a percentage of $\beta$-actin or $\beta$-tubulin. Three independent experiments were carried out.

\subsection{Cell Cycle Analysis}

Cell cycle distribution was assessed using propidium iodide (PI), which measures the DNA content in the cells. PC3 $\left(1 \times 10^{6}\right.$ cells $)$ and DU145 $\left(1.5 \times 10^{6}\right)$ cells were seeded in $100 \times 20 \mathrm{~mm}$ Petri dishes. After allowing the cells to attach to the surface for a period of $24 \mathrm{~h}$, the cells were treated with either 6 or $8 \mu \mathrm{M}$ of the compounds (SAHA, Jazz90 and Jazz167) or vehicle control (0.5\% DMSO). Based on the results from the time-course experiments, time-points were chosen for sample extraction. For PC 3 cells, the cell cycle distribution was analyzed at 24, 48, and $60 \mathrm{~h}$, whereas for DU145 cells, it was performed at 24 and $48 \mathrm{~h}$. Supernatants were collected and cells were harvested and washed with PBS. Cells were then fixed in 70\% ethanol. Subsequently, cells were rehydrated with PBS and stained with PI RNase in the dark at $4{ }^{\circ} \mathrm{C}$. The samples were analyzed using the $\mathrm{BC}$ Gallios flow cytometer (Beckman Coulter, Auckland, New Zealand). The FlowJo software was used to determine the percentage of cells in each of the phases of the cell cycle. Results were expressed as a percentage of cell number in each of the cell cycle phases. Three independent experiments were carried out.

\subsection{Apoptosis Analysis}

PC3 $\left(1 \times 10^{6}\right.$ cells $)$ and DU145 $\left(1.5 \times 10^{6}\right.$ cells $)$ were seeded in $100 \times 20 \mathrm{~mm}$ Petri dishes. After $24 \mathrm{~h}$, the cells were treated with 6 and $8 \mu \mathrm{M}$ of SAHA, Jazz90, and Jazz167 or vehicle control $(0.5 \%$ DMSO). Apoptosis was analyzed at the same time points as the cell cycle distribution. A similar procedure to harvest the cells as in the cell cycle analysis experiments was used. The cells were then suspended in Annexin-V APC for a period of $5 \mathrm{~min}$, followed by PI staining. The samples were analyzed using the BC Gallios flow cytometer. The data were analyzed using Kaluza software (Beckman Coulter, Auckland, New Zealand). Three independent experiments were carried out.

\subsection{Statistical Analysis}

Time course experiments were assessed using a two-way ANOVA followed by Bonferroni's post hoc test. For experiments that did not have time as an independent variable, one-way ANOVA was used, followed by Bonferroni's post hoc test. $p<0.05$ was the minimum requirement for a significant difference.

Supplementary Materials: The following are available online at https: / www.mdpi.com/1424-8 247/14/2/103/s1: Figure S1: Cytotoxicity of Jazz90, Jazz167 and SAHA in (a) PC3, (b) DU145, (c) LnCaP, (d) PNT1A, and (e) NIH 3T3 cells treated at concentrations ranging from 0-150 $\mu$ M; Figure S2: Kinetic assays following drug treatments (a) SAHA, (b) Jazz90, (c) Jazz167, and (d) TSA (positive control) on nuclear lysates of HeLa cells; Figure S3: Kinetic assays in PC3 nuclear lysates using the drugs (a) SAHA, (b) Jazz90, and (c) Jazz167; Figure S4: All blots for the acetyl-H3 protein used for densitometry; Figure S5: All blots for cyclin D in the cell lines PC3 and Du145; Figure S6: All blots for cyclin B in the cell lines PC3 and Du145; Figure S7: All blots for p27kip1 in the cell lines PC3 and Du145; Figure S8: All blots for p21 in the cell lines PC3 and Du145; Figure S9: Analysis of apoptosis and necrosis in DU145 cells; Figure S10: Expression profile of apoptotic protein Bcl-2 in PC3 and Du145 cells; and Figure S11: Compound withdrawal effects in prostate cancer cells.

Author Contributions: Conceptualization, Z.R. and R.J.R.; methodology, Z.R.; formal analysis, Z.R., J.D.A.T., and R.J.R.; investigation, Z.R.; resources, R.J.R, M.H., J.D.A.T., and C.G.H.; writingoriginal draft preparation, Z.R.; writing-review and editing, Z.R., J.D.A.T., M.H., C.G.H., and R.J.R.; supervision, M.H. and R.J.R.; project administration, R.J.R; funding acquisition, M.H. and R.J.R. All authors have read and agreed to the published version of the manuscript. 
Funding: This research was funded by a University of Otago Research Grant, grant number 116396. M.H. was supported by a Sir Charles Hercus Health Research Fellowship through the Health Research Council of New Zealand.

Institutional Review Board Statement: Not applicable.

Informed Consent Statement: Not applicable.

Data Availability Statement: The data presented in this study are available within the article, associated supplemental materials, or on request from the corresponding author.

Acknowledgments: The authors would like to thank Mhairi Nimick for technical assistance.

Conflicts of Interest: The authors declare no conflict of interest. The funders had no role in the design of the study; in the collection, analyses, or interpretation of data; in the writing of the manuscript; or in the decision to publish the results.

\section{References}

1. Rawla, P. Epidemiology of Prostate Cancer. World J. Oncol. 2019, 10, 63-89. [CrossRef] [PubMed]

2. Global Burden of Disease Cancer Collaboration; Fitzmaurice, C.; Allen, C.; Barber, R.M.; Barregard, L.; Bhutta, Z.A.; Brenner, H.; Hancock, J. Global, Regional, and National Cancer Incidence, Mortality, Years of Life Lost, Years Lived With Disability, and Disability-Adjusted Life-years for 32 Cancer Groups, 1990 to 2015: A Systematic Analysis for the Global Burden of Disease Study. JAMA Oncol. 2017, 3, 524. [CrossRef] [PubMed]

3. Saraon, P.; Drabovich, A.P.; Jarvi, K.A.; Diamandis, E.P. Mechanisms of Androgen-Independent Prostate Cancer. EJIFCC 2014, 25, 42-54. [PubMed]

4. Huang, Y.; Jiang, X.; Liang, X.; Jiang, G. Molecular and cellular mechanisms of castration resistant prostate cancer. Oncol. Lett. 2018. [CrossRef]

5. Sartor, A.O. Progression of metastatic castrate-resistant prostate cancer: Impact of therapeutic intervention in the post-docetaxel space. J. Hematol. Oncol. 2011, 4, 18. [CrossRef] [PubMed]

6. $\quad$ Bluemn, E.G.; Coleman, I.M.; Lucas, J.M.; Coleman, R.T.; Hernandez-Lopez, S.; Tharakan, R.; Bianchi-Frias, D.; Dumpit, R.F.; Kaipainen, A.; Corella, A.N.; et al. Androgen Receptor Pathway-Independent Prostate Cancer Is Sustained through FGF Signaling. Cancer Cell. 2017, 32, 474-489.e6. [CrossRef] [PubMed]

7. Zhou, J.; Wang, Y.; Xiang, S.; Chan, F.L. Towards understanding androgen receptor-independent prostate cancer: An evolving paradigm. Transl. Cancer Res. 2020, 9, 415-417. [CrossRef]

8. Shah, R.B.; Mehra, R.; Chinnaiyan, A.M.; Shen, R.; Ghosh, D.; Zhou, M. Androgen-Independent Prostate Cancer Is a Heterogeneous Group of Diseases: Lessons from a Rapid Autopsy Program. Cancer Res. 2004, 64, 9209-9216. [CrossRef] [PubMed]

9. Abida, W.; Cyrta, J.; Heller, G.; Prandi, D.; Armenia, J.; Coleman, I.; Cieslik, M.; Benelli, M.; Robinson, D.; Van Allen, E.M.; et al. Genomic correlates of clinical outcome in advanced prostate cancer. Proc. Natl. Acad. Sci. USA 2019, 11428-11436. [CrossRef]

10. Tucci, M.; Caffo, O.; Buttigliero, C.; Cavaliere, C.; D'aniello, C.; Di Maio, M.; Kinspergher, S.; Maines, F.; Rizzo, M.; Rossetti, S.; et al. Therapeutic options for first-line metastatic castration-resistant prostate cancer: Suggestions for clinical practise in the CHAARTED and LATITUDE era. Cancer Treat Rev. 2019, 74, 35-42. [CrossRef]

11. Fléchon, A.; Pouessel, D.; Ferlay, C.; Perol, D.; Beuzeboc, P.; Gravis, G.; Joly, F.; Oudard, S.; Deplanque, G.; Zanetta, S.; et al. Phase II study of carboplatin and etoposide in patients with anaplastic progressive metastatic castration-resistant prostate cancer (mCRPC) with or without neuroendocrine differentiation: Results of the French Genito-Urinary Tumor Group (GETUG) P01 trial. Ann. Oncol. 2011, 22, 2476-2481. [CrossRef] [PubMed]

12. Li, Y.; Seto, E. HDACs and HDAC Inhibitors in Cancer Development and Therapy. Cold Spring Harb. Perspect. Med. 2016, 6, a026831. [CrossRef] [PubMed]

13. Ropero, S.; Esteller, M. The role of histone deacetylases (HDACs) in human cancer. Mol. Oncol. 2007, 1, 19-25. [CrossRef] [PubMed]

14. Weichert, W. HDAC expression and clinical prognosis in human malignancies. Cancer Lett. 2009, 280, 168-176. [CrossRef] [PubMed]

15. Weichert, W.; Röske, A.; Gekeler, V.; Beckers, T.; Stephan, C.; Jung, K.; Fritzsche, F.R.; Niesporek, S.; Denkert, C.; Dietel, M.; et al. Histone deacetylases 1, 2 and 3 are highly expressed in prostate cancer and HDAC2 expression is associated with shorter PSA relapse time after radical prostatectomy. Br. J. Cancer 2008, 98, 604-610. [CrossRef] [PubMed]

16. Cheng, J.; Wang, D.; Wang, Z. Yeh ETH. SENP1 Enhances Androgen Receptor-Dependent Transcription through Desumoylation of Histone Deacetylase 1. Mol. Cell Biol. 2004, 24, 6021-6028. [CrossRef]

17. Chiao. Deficient histone acetylation and excessive deacetylase activity as epigenomic marks of prostate cancer cells. Int. J. Oncol. 2009, 35. [CrossRef]

18. Lee, H.-Z.; Kwitkowski, V.E.; Del Valle, P.L.; Ricci, M.S.; Saber, H.; Habtemariam, B.A.; Bullock, J.; Bloomquist, E.; Li Shen, Y.; Chen, X.H.; et al. FDA Approval: Belinostat for the Treatment of Patients with Relapsed or Refractory Peripheral T-cell Lymphoma. Clin. Cancer Res. 2015, 21, 2666-2670. [CrossRef] 
19. Raedler, L.A. Farydak (Panobinostat): First HDAC Inhibitor Approved for Patients with Relapsed Multiple Myeloma. Am. Health Drug Benefits 2016, 9, 84-87.

20. Barbarotta, L.; Hurley, K. Romidepsin for the Treatment of Peripheral T-Cell Lymphoma. J. Adv. Pract. Oncol. 2015, 6, 22-36.

21. Mann, B.S.; Johnson, J.R.; Cohen, M.H.; Justice, R.; Pazdur, R. FDA Approval Summary: Vorinostat for Treatment of Advanced Primary Cutaneous T-Cell Lymphoma. Oncologist 2007, 12, 1247-1252. [CrossRef] [PubMed]

22. Jiang, Z.; Li, W.; Hu, X.; Zhang, Q.; Sun, T.; Cui, S.; Wang, S.; Ouyang, Q.; Yin, Y.; Geng, C.Z.; et al. Tucidinostat plus exemestane for postmenopausal patients with advanced, hormone receptor-positive breast cancer (ACE): A randomised, double-blind, placebo-controlled, phase 3 trial. Lancet Oncol. 2019, 20, 806-815. [CrossRef]

23. Hanif, M.; Arshad, J.; Astin, J.W.; Rana, Z.; Zafar, A.; Movassaghi, S.; Leung, E.; Patel, K.; Söhnel, T.; Reynisson, J.; et al. A Multitargeted Approach: Organorhodium Anticancer Agent Based on Vorinostat as a Potent Histone Deacetylase Inhibitor. Angew. Chem. Int. Ed. 2020, 132, 14717-14722. [CrossRef]

24. Ritchie, T.J.; Macdonald, S.J.F. The impact of aromatic ring count on compound developability-are too many aromatic rings a liability in drug design? Drug Discov. Today 2009, 14, 1011-1020. [CrossRef]

25. Meier, S.M.; Hanif, M.; Adhireksan, Z.; Pichler, V.; Novak, M.; Jirkovsky, E.; Hartinger, C.G. Novel metal(ii) arene 2pyridinecarbothioamides: A rationale to orally active organometallic anticancer agents. Chem. Sci. 2013, 4, 1837. [CrossRef]

26. Lauffer, B.E.L.; Mintzer, R.; Fong, R.; Mukund, S.; Tam, C.; Zilberleyb, I.; Flicke, B.; Ritscher, A.; Fedorowicz, G.; Vallero, R.; et al. Histone Deacetylase (HDAC) Inhibitor Kinetic Rate Constants Correlate with Cellular Histone Acetylation but Not Transcription and Cell Viability. J. Biol. Chem. 2013, 288, 26926-26943. [CrossRef]

27. Mahanta, N.; Szantai-Kis, D.M.; Petersson, E.J.; Mitchell, D.A. Biosynthesis and Chemical Applications of Thioamides. ACS Chem. Biol. 2019, 14, 142-163. [CrossRef]

28. Laurenzana, A.; Balliu, M.; Cellai, C.; Romanelli, M.N.; Paoletti, F. Effectiveness of the Histone Deacetylase Inhibitor (S)-2 against LNCaP and PC3 Human Prostate Cancer Cells. PLoS ONE 2013, 8, e58267. [CrossRef]

29. Patra, N.; De, U.; Kim, T.H.; Lee, Y.J.; Ahn, M.Y.; Kim, N.D.; Yoon, J.H.; Choi, W.S.; Moon, H.R.; Lee, B.M.; et al. A novel histone deacetylase (HDAC) inhibitor MHY219 induces apoptosis via up-regulation of androgen receptor expression in human prostate cancer cells. Biomed. Pharm. 2013, 67, 407-415. [CrossRef]

30. Ni, X.; Li, L.; Pan, G. HDAC inhibitor-induced drug resistance involving ATP-binding cassette transporters (Review). Oncol. Lett. 2015, 9, 515-521. [CrossRef]

31. Wang, H.; Huang, C.; Zhao, L.; Zhang, H.; Yang, J.M.; Luo, P.; Zhan, B.-X.; Pan, Q.; Li, J.; Wang, B.-L. Histone deacetylase inhibitors regulate P-gp expression in colorectal cancer via transcriptional activation and mRNA stabilization. Oncotarget 2016, 7. [CrossRef] [PubMed]

32. Tang, H.M.; Kuay, K.T.; Koh, P.F.; Asad, M.; Tan, T.Z.; Chung, V.Y.; Lee, S.C.; Thiery, J.P.; Huang, R.Y.-J. An epithelial marker promoter induction screen identifies histone deacetylase inhibitors to restore epithelial differentiation and abolishes anchorage independence growth in cancers. Cell Death Discov. 2016, 2, 16041. [CrossRef] [PubMed]

33. Kortenhorst, M.S.; Wissing, M.D.; Rodriguez, R.; Kachhap, S.K.; Jans, J.J.; Van der Groep, P.; Verheul, H.M.W.; Gupta, A.; Aiyetan, P.O.; Van der Wall, E.; et al. Analysis of the genomic response of human prostate cancer cells to histone deacetylase inhibitors. Epigenetics 2013, 8, 907-920. [CrossRef] [PubMed]

34. Shi, X.-Y.; Ding, W.; Li, T.-Q.; Zhang, Y.-X.; Zhao, S.-C. Histone Deacetylase (HDAC) Inhibitor, Suberoylanilide Hydroxamic Acid (SAHA), Induces Apoptosis in Prostate Cancer Cell Lines via the Akt/FOXO3a Signaling Pathway. Med. Sci. Monit. 2017, 23, 5793-5802. [CrossRef] [PubMed]

35. Seim, I.; Jeffery, P.L.; Thomas, P.B.; Nelson, C.C.; Chopin, L.K. Whole-Genome Sequence of the Metastatic PC3 and LNCaP Human Prostate Cancer Cell Lines. G3 Genes Genomes Genetics 2017, 7, 1731-1741. [CrossRef] [PubMed]

36. Vlietstra, R.J.; van Alewijk, D.C.; Hermans, K.G.; van Steenbrugge, G.J.; Trapman, J. Frequent inactivation of PTEN in prostate cancer cell lines and xenografts. Cancer Res. 1998, 58, 2720-2723. [PubMed]

37. Chappell, W.H.; Lehmann, B.D.; Terrian, D.M.; Abrams, S.L.; Steelman, L.S.; McCubrey, J.A. p53 expression controls prostate cancer sensitivity to chemotherapy and the MDM2 inhibitor Nutlin-3. Cell Cycle 2012, 11, 4579-4588. [CrossRef]

38. Chuang, M.-J.; Wu, S.-T.; Tang, S.-H.; Lai, X.-M.; Lai, H.-C.; Hsu, K.-H.; Sun, G.-H.; Chang, S.-Y.; Yu, D.-S.; Hsiao, P.-W.; et al. The HDAC Inhibitor LBH589 Induces ERK-Dependent Prometaphase Arrest in Prostate Cancer via HDAC6 Inactivation and Down-Regulation. PLoS ONE 2013, 8, e73401. [CrossRef]

39. Inks, E.S.; Josey, B.J.; Jesinkey, S.R.; Chou, C.J. A Novel Class of Small Molecule Inhibitors of HDAC6. ACS Chem. Biol. 2012, 7, 331-339. [CrossRef]

40. Kim, I.A.; No, M.; Lee, J.M.; Shin, J.H.; Oh, J.S.; Choi, E.J.; Kim, H., II; Atadja, P.; Bernhard, E.J. Epigenetic modulation of radiation response in human cancer cells with activated EGFR or HER-2 signaling: Potential role of histone deacetylase 6. Radiother. Oncol. 2009, 92, 125-132. [CrossRef]

41. Mokhtari, R.B.; Homayouni, T.S.; Baluch, N.; Morgatskaya, E.; Kumar, S.; Das, B.; Yeger, H. Combination therapy in combating cancer. Oncotarget 2017, 8, 38022-38043. [CrossRef] [PubMed]

42. Ruscetti, M.; Leibold, J.; Bott, M.J.; Fennell, M.; Kulick, A.; Salgado, N.R.; Chen, C.C.; Ho, Y.J.; Sanchez-Rivera, F.J.; Feucht, J.; et al. NK cell-mediated cytotoxicity contributes to tumor control by a cytostatic drug combination. Science 2018, 362, 1416-1422. [CrossRef] [PubMed] 
43. Skehan, P.; Storeng, R.; Scudiero, D.; Monks, A.; McMahon, J.; Vistica, D. New Colorimetric Cytotoxicity Assay for AnticancerDrug Screening. JNCI J. Natl. Cancer Inst. 1990, 82, 1107-1112. [CrossRef]

44. Smith, P.K.; Krohn, R.I.; Hermanson, G.T.; Mallia, A.K.; Gartner, F.H.; Provenzano, M.D.; Fujimoto, E.K.; Goeke, N.M.; Olson, B.J.; Klenk, D.C.; et al. Measurement of protein using bicinchoninic acid. Anal. Biochem. 1985, 150, 76-85. [CrossRef] 